\title{
IMPLEMENTASI PENDIDIKAN KARAKTER ISLAM DI ERA MILENIAL PADA PONDOK PESANTREN MAHASISWA
}

\author{
Rahmatullah 1), Akhmad Said ${ }^{2)}$ \\ ${ }^{1}$ STAI Ma’had Aly Al-Hikam Malang \\ email: Rahmat11@staima-alhikam.ac.id \\ 2 STAI MA’had Aly Al-Hikam Malang \\ email: seachsaidahmad@gmail.com
}

\begin{abstract}
Islamic character education for students in the millennial arena is absolutely necessary, because students are the nation's assets that are agents of change and future leaders. Education to appreciate the importance of moral values shapes the sense of wanting to do good and being able to do good is the ideal that is expected to be realized in an era of increasingly rapid change. Therefore we need the formulation of character education in accordance with the circumstances of the era and in dealing with the challenges. Research with a phenomenological approach needs to be carried out to find out the implementation of Islamic character education in the minelial era in Islamic educational institutions (Islamic boarding schools for students), so that by using qualitative research methods it is expected to find effective and efficient implementation of character education. The results of this study include the implementation of 24-hour education including $\mathrm{R} i$ 'ayah wal Ershad (caregiving), Ta'dib wat Tahdzib (santri), and Dirosah / Tadris Wat Ta'liim (Teacbing) plus four others namely pesantren traditions, pesantren souls, discipline, and organizational / management structure can be used as reference material in improving the quality of character education in Indonesia.
\end{abstract}

Kata kunci: pendidikan, karakter Islam, pesantren

\section{Pendahuluan}

Mahasiswa merupakan aset bangsa yang menjadi agen perubahan (agent of change) dan calon pemimpin di masa yang akan datang. Sebagai golongan pelajar dan atau penuntut ilmu, mahasiswa perlu mendapatkan pendidikan yang bermutu dan berkualitas baik dari segi kognitif, afektif dan psikomotorik.

Pendidikan karakter Islam bagi kalangan mahasiswa diera milenial merupakan salah satu alternatif pendidikan yang dibutuhkan oleh mahasiswa. Pendidikan karakter yang bertuuuan untuk menghargai pentingnya nilai- nilai moral, membentuk rasa ingin berbuat baik, dan mampu berbuat baik adalah cita-cita yang diharapkan mampu diwujudkan di era milenial dan era perubahan yang semakin cepat.

1 Akhmad Said, "Kepemimpinan Kepala Sekolah Dalam Melestarikan Budaya Mutu Sekolah", Jurnal Evaluasi 2.1 2018. Hlm 264 
Formulasi pendidikan karakter yang sesuai dengan keadaan jaman saat ini dalam menghadapi perubahan dan tantangan jaman serta sesuai dengan kebutuhan mahasiswa di masa yang akan datang mutlak dibutuhkan. Tantangan global, perubahan sosial dan budaya serta tantangan masa yang akan datang harus dapat dibentengi dan diantisipasi dengan pendidikan yang bermutu dan sesuai dengan nilainilai bangsa, nilai-nilai budaya, dan nilai-nilai agama.

Lebih lanjut, Dr. Marvin Berkowitz menyatakan bahwa:

Effective character education is not adding a program or set of programs to a school. Rather it is a transformation of the culture and life of the school. ${ }^{2}$

Dapat diartikan secara bebas pendidikan karakter yang efektif tidak menambahkan program atau kumpulan program ke sekolah. Sebaliknya itu adalah transformasi budaya dan kehidupan sekolah (lembaga pendidikan).

Transformasi budaya dan kehidupan sekolah ini patut digaris bawahi dan dapat dijadikan sebagai pertanda bahwa pendidikan karakter di pondok pesantren yang dilaksanakan selama 24 jam merupakan salah satu bentuk dari proses pembelajaran tentang transformasi budaya dan kehidupan sekolah.

Budaya sekolah adalah perpaduan nilai-nilai, keyakinan, asumsi, pemahaman, dan harapan yang diyakini oleh warga sekolah serta dijadikan pedoman bagi perilaku dan pemecahan masalah internal dan eksternal yang mereka hadapi dan merupakan dasar dan landasan bagi perubahan dalam hidup pribadi atau kelompok. ${ }^{3}$

Terkait dengan beberapa hal tersebut di atas, salah satu lembaga pendidikan yang telah mengimplementasikan pendidikan karakter Islam adalah pondok pesantren mahasiswa Al-Hikam Malang (disingkat: PESMA). PESMA al-Hikam telah mengimplementasikan pendidikan karakter dengan kedua ciri utama di atas, yakni transformasi budaya dan kehidupan sekolah.

PESMA al-Hikam memiliki cara pandang jauh kedepan yakni bertujuan untuk mencetak santri-mahasiswa berkarakter Islami sebagai calon masyarakat Islam (khususnya Indonesia) yang bermoral dan atau berkarakter serta berprilaku agamis. Pesma Al-Hikam tentunya memiliki latar belakang, pengalaman dan penerapan yang

${ }^{2}$ Mike Frye, at all. Character Education Informational Handbook and Guide. Public Schools of North Carolina State Board of Education Department of Public Instruction Division of Instructional Services Character Education. 2002. Hlm. 2

3 Akhmad Said, Kepemimpinan Kepala Sekolah Dalam Melestarikan Budaya Mutu Sekolah journal Evaluasi 2.1 .2018. Hlm 257 
dilakukan sampai saat ini yang patut dikaji dan diteliti utamanya dalam hal penempaan moral dan karakter bagi santri.

Oleh karenanya beberapa hal tersebut di atas, maka penelitian tentang implementasi pendidikan karakter Islam di era milenial pada pondok pesantren mahasiswa ini sangat penting dan unik untuk dikaji dan diteliti serta ditelaah lebih mendalam.

\section{Metodologi}

Penelitian ini menggunakan pendekatan kualitatif dengan desain penelitian pustaka (library research) yakni dengan mengkaji ulang konsep-konsep pengembangan kurikulum dan problematikanya dari para ahli, kemudian penulis berusaha untuk membuat sintesa dari pendapat para ahli tersebut. Adapun analisisnya menggunakan analisis isi (content analysis), hal ini penulis lakukan dengan cara menganalisis secara mendalam mengenai konsep-konsep yang telah dikemukakan para ahli. Untuk teknik keabsahan datanya peneliti menggunakan triangulasi sumber, yakni mengkroscek beberapa sumber baik berupa buku, artikel dan lain sebagainya yang menjadi literatur dalam penulisan artikel ini.

\section{Pembahasan}

\section{A. Pentingnya Pendidikan Karakter Bagi Mahasiswa di Era Milenial}

Sebagaimana diketahui bahwa secara etimologi kata karakter berasal dari bahasa latin "kharakter", "kharassein". "kharax", yang kemudian diterjemahkan ke dalam bahasa Inggris dengan kata character dan bahasa Indonesia karakter. ${ }^{4}$ Kata ini memiliki arti tabiat; sifat-sifat kejiwaan, akhlak atau budi pekerti yg membedakan seseorang dengan yang lain. ${ }^{5}$

Merujuk pendapat Kevin Ryan dan Karen E Bohlin dalam bukunya yang berjudul building charakter in schools menyatakan bahwa:

4 Jakaria Umro. Pendidikan Karakter Dalam Perspektif Islam ( Kajian Penerapan Pendidikan Karakter Anak dalam Keluarga ) Jurnal Al-Makrifat Vol 2, No 1, April 2017. Hlm. 101

${ }^{5}$ Dendy Sugono dan Meity Taqdir Qodratillah (eds). Kamus Bahasa Indonesia. Jakarta: Pusat Bahasa, 2008. hlm.639. 
TA'LIMUNA, Vol. 9, No. 02, September 2019, ISSN 2085-2975

Knowing the good, loving the good, and doing the good. So, when you build character, you must address the cognitive, the emotional, and the behavioral- the head, the heart, and the hand. ${ }^{6}$

Mengetahui yang baik, mencintai yang baik, dan melakukan kebaikan. Jadi, ketika Anda membangun karakter, Anda harus mengatasi kognitif, emosional, dan perilaku - kepala, hati, dan tangan.

Dr. Martin Luther King berpendapat bahwa; ${ }^{7}$ intelligence plus character that is the goal oftrue education (kecerdasan yang berkarakter adalah tujuan akhir pendidikan yang sebenarnya) serta tujuan pendidikan karakter untuk mengetahui kebaikan (knowing the good), mencintai kebaikan (loving the good), dan melakukan kebaikan (doing the good), maka pendidikan karakter bagi mahasiswa sangat di perlukan dan sangat penting, mengingat mahasiswa merupakan generasi penerus bangsa yang perlu dididik dan diarahkan untuk mengetahui, mencintai, dan melakukan kebaikan.

Mengingat ketiga hal tersebut diatas, yaitu mengetahui yang baik, mencintai yang baik, dan melakukan kebaikan menurut penulis ketiga hal tersebut sudah menjadi hal yang langka di era milenial ini. Dengan semakin cepatnya arus informasi sehingga setiap orang akan mengalami kesulitan dalam mengkonfirmasi kebenaran dan kebaikan dari sumber informasi. Pengetahuan mahasiswa yang dibentuk dari berbagai macam informasi baik dari televisi, radio, internet, dan media sosial akan memberikan dampak terhadap pengetahuan mereka akan informasi tersebut, mengingat konten informasi yang kurang baik banyak beredar di dunia digital.

Lebih lanjut, era milenial yang ditandai dengan arus informasi yang tanpa batas dan arus globalisasi akan memberikan dampak negatif yang ditimbulkan, karena akan membuka masuknya budaya luar yang belum tentu sesuai dengan budaya Indonesia. Mahasiswa sebagai generasi milenial merupakan generasi yang rentan akan berbuat sesuatu yang kurang baik karena generasi ini mempunyai karakteristik sebagai berikut: ${ }^{8}$ pertama, memiliki karakter yang berbeda tergantung dari strata ekonomi dan keluarga. kedua, pola komunikasi yang terbuka jika dibandingkan dengan generasi sebelumnya. ketiga, pengguna media sosial yang sangat fanatik serta kehiupannya lebih banyak dipengaruhi oleh perkembangan teknologi dan informasi. Keempat,

\footnotetext{
${ }^{6}$ Kevin Ryan dan Karen E Bohlin. building charakter in schools Practical ways to bring moral intruction to life. San Fransisco:Jossey-Bass Publishers. 1999. Hlm. x-xi

${ }^{7}$ Mike Frye, at all. Character Education Informational Handbook and Guide...hlm. 1

${ }^{8}$ Yanuar Surya Putra, Theoritical Review: Teori Perbedaan Generasi. Among Makarti. Vol.9 No. 18. Desember 2016. Hlm. 129
} 
terbuka dengan pandangan politik dan ekonomi, dan keempat, memiliki karakter yang punya perhatian lebih terhadap kekayaan duniawi.

Perhatian yang berlebihan terhadap kekayaan merupakan sumber dari perilaku yang kurang baik. Dalam hal ini Imam al-ghazali menyatakan bahwa perhatian berlebihan terhadap dunia (bubbud dunya) merupakan akar dari segaladosa.? Hal inilah yang perlu menjadi perhatian bagi pengelola pendidikan khususnya bagi mahasiswa umumnya peserta didik disegala jenjang.

Lenih lanjut, penggunaan internet dan media sosial secara berlebihan sebagai salah satu karakter mahasiswa era milenial juga perlu menjadi perhatian sehingga diperlukan pendidikan karakter bagi mahasiswa, karena penggunakan internet dan media sosial akan memberikan dampak yang kurang baik bagi mahasiswa khususnya. Merujuk kepada hasil penelitian tentang dampak kecanduan internet, bahwa dampak negatif penggunaan internet lebih besar dibandingkan dengan dampak positifnya, diantaranya adalah berkurangnya interaksi sosial secara langsung, seringnya menundanunda pekerjaan, menurunnya prestasi belajar, dan lain-lain. ${ }^{10}$

Selain hal tersebut di atas, pendidikan karakter di Indonesia masih jauh tertinggal apabila dibandingkan dengan negara tetangga. Pendidikan di Indonesia masih mengedepakan aspek kognitif atau keilmuan dan atau pengetahuan saja daripada aspek karakter dan atau akblakul karimah. ${ }^{11}$ Menurut peneliti pendidikan karakter di lembaga pendidikan formal (perguruan tinggi) bagi mahasiswa masih sangat terbatas, dan sangat minim karena keterbatasan waktu, sarana dan prasarana dan lain-lain, maka diperlukan alternatif lembaga pendidikan yang fokus menangani permasalahan moral dan atau etika mahasiswa.

\section{B. Karakteristik Pondok Pesantren mahasiswa}

Secara etimologi pesantren mahasiswa umumnya menggunakan beberapa istilah kata yaitu pondok pesantren mahasiswa atau pesantren luhur atau ma"had aly yang berarti kata ma'had adalah pondok sedangkan kata aly berarti tingkat tinggi.

${ }^{9}$ Abi Hamid Muhammad bin Muhammad al-Ghazaly. Ihya' ulumuddin hal:276

${ }^{10}$ Siti Nurina Hakim dan Aliffatullah Alyu Raj Dampak kecanduan internet (internet addiction) pada remaja. Prosiding Temu Ilmiah X Ikatan Psikologi Perkembangan Indonesia. HIm. 280-282

11 Kalfaris Lalo, Menciptakan Generasi Milenial Berkarakter dengan Pendidikan Karakter guna Menyongsong Era Globalisasi. Jurnal Ilmu Kepolisian Volume 12 Nomor 2 Juli 2018. Hlm. 68 
Penggunaan beberapa istilah tersebut digunakan oleh beberapa lembaga pendidikan seperti ma'had aly Sunan Ampel yang berada dilingkungan Universitas Islam Negeri (UIN) Maulana Malik Ibrahim Malang, pesantren luhur seperti di Lembaga Tinggi Pesantren Luhur yang didirikan oleh alm.Prof. Dr. KH. Achmad Mudlor, SH., dan Pesantren mahasiswa (PESMA) Al-Hikam Malang maupun Pesma Al-Hikam Jakarta yang berada di samping Universitas Indonesia (UI) Depok.

Beberapa istilah tersebut sesungguhnya mempunyai arti yang sama yakni lembaga pendidikan tempat mencari ilmu para santri dari kalangan mahasiswa. Tentunya fungsi dari pesantren mahasiswa bukan hanya sebagai tempat tinggal akan tetapi lebih dari pada hal tersebut, mahasiswa dilingkungan pesantren yang disebut dengan mahasantri (mahasiswa-santri) diberi tambahan ilmu agama, moral atau akblakul karimah dan lain sebagainya.

Keberadaan pesantren mahasiswa dianggap sebagai sesuatu yang penting untuk terus dikembangkan guna menciptakan lingkungan yang religius. Melihat pertumbuhan dan perkembangan pesantren mahasiswa, menurut penulis dilihat dari segi latar belakang berdirinya terdapat tiga klasifikasi pesantren mahasiswa, yakni: Tipe Pertama, pesantren mahasiswa yang sejak awal pendiriannya memang dikhususkan bagi para mahasiswa seperti pondok pesantren mahasiswa Al-Hikam Malang. ${ }^{12}$ Tipe Kedua, pondok pesantren yang didirikan oleh lembaga formal/ perguruan tinggi seperti di Universitas Islam Negeri Maulana Malik Ibrahim Malang yang mendirikan Ma'had Aly Sunan Ampel. ${ }^{13}$ Tipe Ketiga, pondok pesantren yang mendirikan perguruan tinggi seperti pesanten Salafiyah Syafie iyah sukorejo situbondo didirikan oleh KHR. Asy'ad Syamsyul Arifin, pada tanggal 14 Maret 1968 telah berdiri perguruan tinggi dengan nama Ibrahimy saat ini bernama Institut Agama Islam Ibrahimy (IAII), Pondok Modern Darussalam Gontor yang mendirikan Institut Studi Islam Darussalam (ISID) saat ini bernama Universitas Darussalam Gontor (UNIDA Gontor), Pondok pesantren Darul Ulum Peterongan Jombang mendirikan STAIDU (Sekolah Tinggi Agama Islam Darul Ulum) yang kemudian berkembang menjadi UNIPDU (Universitas Pesantren Tinggi Darul Ulum) Jombang dan lain- lain.

\footnotetext{
${ }^{12}$ Dokumen sejarah berdirinya PESMA Al-Hikam Malang. Hlm 2-4

${ }^{13} \mathrm{http} / / / \mathrm{msaa} . u i n-m a l a n g . a c . i d / s a m p l e-p a g e /$ diakses 1 Oktober 201. Jam 10.38 Am.
} 
Ketiga pesantren mahasiswa diatas, memiliki karakteristik yang berbeda-beda antara satu dengan yang lainnya, baik dari segi sistem pendidikan dan pengajaran maupun dari segi kepemimpinan atau manajemen. Menurut peneliti beberapa perbedaan dan karakteristik tersebut diantaranya:

1. Input santri, Pesantren mahasiswa tipe pertama menerima santri dari mahasiswa yang kuliah disekitar pesantren tersebut tanpa membedakan apakah perguruan tinggi tersebut berstatus swasta atau negeri. Berbeda halnya dengan pesantren mahasiswa tipe kedua yang hanya menerima santri dari kalangan sendiri atau santri dari mahasiswa yang studi dikampus tersebut. Berbeda pula halnya dengan pesantren mahasiswa tipe ketiga yang menerima santri dari semua jenjang pendidikan bahkan yang tidak menyandang predikat sebagai mahasiswa karena pesantren tipe ketiga tidak hanya memfokuskan diri pada pendidikan kalangan mahasiswa, akan tetapi pada jenjang pendidikan yang lain (jenjang dasar, menengah, dan atas).

2. Proses pendidikan atau pembelajaran. Proses pendidikan atau pembelajaran misalnya dalam hal terkait dengan waktu menempuh pendidikan. Pada pesantren tipe pertama adalah selama santri menjadi mahasiswa atau minimal antara 4 (empat) sampai 4,5 (empat setengah tahun), sedangkan pada pesantren tipe kedua biasanya hanya pada 1 (satu) tahun pertama atau 2 (dua) semester, sedangkan pada tipe ketiga proses pendidikannya bisa dimulai sebelum menjadi mahasiswa dan sampai mereka lulus kuliah atau bahkan lebih lama. Tentunya perbedaan proses pendidikan dan pembelajaran ini juga terkait dengan kurikulum, silabus dan atau pengajian serta tatacara pembelajaran. Perbedaan juga bisa terdapat pada aturanaturan pesantren yang berbeda antara satu dengan yang lain. Output santri/alumni

3. Output santri/alumni pesantren mahasiswa pada tipe pertama dan tipe ketiga adalah keluaran santri yang telah lulus disebuah lembaga pendidikan non formal pondok pesantren. Hal ini tidak berlaku bagi pesantren tipe kedua karena outputnya adalah sebagai lulusan dari pendidikan formal saja (perguruan tinggi).

\section{Implementasi Pendidikan Karakter di Pondok Pesantren Mahasiswa al- Hikam Malang}

Sebagai lembaga pendidikan non formal, pondok pesantren mahasiswa (PESMA) Al-Hikam telah berpengalaman selama lebih dari 25-tahun (berdiri pada 
TA'LIMUNA, Vol. 9, No. 02, September 2019, ISSN 2085-2975

tahun 1990). ${ }^{14}$ Pesma Al-Hikam memiliki kriteria dan karakteristik mahasiswa yang dikembangkan yang sederhana, yakni mahasiswa yang santri atau disingkat dengan mahasantri. MAHASANTRI (mahasiswa-santri) dimaksudkan untuk mencetak generasi dari sisi rasionalitas dan eksperimentasi yang tinggi sebagai bentuk dari ciri khas seorang mahasiswa seperti seorang cendekia dan mempunyai sisi moralitas dan atau karakter serta moralitas yang tinggi dari ciri khas seorang santri seperti para ulama.

Secara harfiyyah cita-cita pesantren ini tertuang dalam visi pesantren yakni mewujudkan komunitas belajar untuk mengembangkan potensi fitrah insaniah yang mengintegrasikan etika Agama, etika ilmiah dan etika sosial. ${ }^{15}$ Sehingga pesantren ini memfokuskan diri dalam hal membangun potensi mahasiswa yang memiliki etika agama Islam yakni taat dan bertakwa kepada Allah SWT, memiliki etika ilmiah yang sesuai dengan zaman yang terus berkembang dan memiliki etika sosial yakni keilmuan dan tanggungjawabnya kepada masyarakat. Hal ini diartikan sebagai santri mahasiswa yang mampu ber-hablum minallah yaitu hubungan vertikal berkaitan dengan ketaatan kepada sang pencipta) dan hablum minannash yaitu hubungan horisontal berkaitan dengan berhubungan terhadap sesama makhluk.

Berangkat dari hal tersebut diatas, pesma Al-Hikam meng-ikhtiarkan profil lulusan santri mahasiswa yang: pertama, Mampu memahami dan mengamalkan syariat Islam dengan baik dan benar, taat beribadah, berdoa, dan berusaha; memiliki etos kerja keras, kerja cerdas dan kerja ikhlas; kedua, berprestasi tinggi dalam bidang ilmu yang ditekuni serta menguasai cara berfikir ilmiah, kritis, kreatif, dan berfikir futuristik; dan ketiga, Cakap dalam menghadapi berbagai persoalan hidup, baik dalam skala lokal, nasional, maupun internasional dan dapat berperan sebagai pelaku perubahan (agent of change) dalam berbagai aspek kehidupan ${ }^{16}$ dan berpegang teguh pada trilgi motto Al-Hikam yaitu Amaliah Agama, Prestasi Ilmiah, Kesiapan Hidup.

Sedangkan secara lebih rinci karakteristik mahasiswa yang diinginkan dan dikembangkan terkandung didalam trilogy motto Pesma Al-Hikam Malang yaitu amaliah agama, prestasi ilmiah dan kesiapan hidup, berikut penjelasan dan uraian ketiganya:

\footnotetext{
${ }^{14}$ Buku profil PESMA Al-Hikam. Hlm 2.

${ }^{15}$ Dokumen proofili pesantren mahasiswa Al-Hikam Malang. Hlm 6.

${ }^{16}$ Dokumen proofili pesantren mahasiswa Al-Hikam Malang. Hlm 8-15.
} 
Pertama, Amaliah Agama adalah kesadaran dan kecakapan dalam memahami mengamalkan ajaran agama Islam dengan baik dan benar. kompetensi yang diharapkan pada point ini adalah:

1. Mampu mengerti dan memahami eksistensi Tuhan sebagai Tuhan yang disembah dan Tuhan yang menciptakan makhluk

2. Mampu memahami dan melaksanakan aturan Allah dan rasulnya baik yang berkaitan antara hubungan manusia dengan Tuhan, manusia dengan manusia maupun manusia dengan sesama makhluk

3. Mampu merefleksikan menjalankan prinsip- prinsip tauhid dan syariah dalam tatacara perilaku yang baik

Kedua, Prestasi Ilmiah. Lulusan pendidikan pesantren Mahasiswa Al Hikam memiliki prestasi akademik yang tinggi dalam program studi (jurusan) yang ditempuh di perguruan tinggi dan memiliki keterampilan berfikir ilmiah sebagai bekal dalam menjalani kehidupan sesuai dengan tuntutan lokal, nasional, maupun global dengan tetap berpegang teguh kepada nilai-nilai Islami. kompetensi diharapkan pada point ini adalah:

1. Pengetahuan, keterampilan dan sikap dalam bidang keahlian tertentu sesuai dengan program studi (jurusan) yang ditempuh di perguruan tinggi.

2. Pengetahuan, keterampilan dan sikap dalam melakukan berbagai aktivitas pengembangan ilmu pengetahuan, teknologi dan seni sesuai dengan program studi yang ditempuh di perguruan tinggi.

3. Pengetahuan, keterampilan dan siap mengemukakannya secara lisan maupun tulisan hasil pengembangan ilmu pengetahuan, teknologi dan seni sesuai dengan program studi yang ditempuh di perguruan tinggi.

Ketiga, Kesiapan Hidup. Adalah kecakapan yang diperlukan untuk menghadapi, memecahkan dan mengelola problem kehidupan agar dapat menjalani kehidupan dengan bahagia, sukses, bermartabat dan diridloi Allah sesuai dengan perannya sebagai khalifah fil ardl. kompetensi diharapkan pada point ini adalah:

1. Memiliki etos untuk terus belajar dan mengembangkan diri

2. Mampu mengembangkan cara berfikir kompleks

3. Mampu berkomunikasi secara efektif

4. Mampu bekerjasama dan membangun team work 
5. Mampu mendayagunakan potensi diri dan lingkungannya untuk peningkatan karir kerja

6. Memiliki tanggung jawab sebagai bagian dari masyarakatnya. ${ }^{17}$

Secara umum pelaksanaan pendidikan dipesantren mahasiswa al-Hikam Malang dilaksanakan selama 24 jam. Kegiatan proses pendidikan di pondok pesantren ini meliputi tujuh bidang yakni bidang kepengasuhan kepengasuhan (Ri'ayah wal Irsyad) bidang pengajaran (Tadris Wat Ta'liim), bidang kesantrian (Ta'dib Wat Tahd₹ib), tradisi pesantren Al-Hikam, jiwa pesantren Al-Hikam, kedisiplinan, struktur organisasi dan manajemen. Metode pendidikan inilah yang menurut Said Agil Siradj sebagai metode pendidikan yang paling menonjol dan paling mendukung dalam pendidikan karakter, karena dengan proses pembelajaran yang dilakukan selama dua puluh empat jam maka para santri dapat mempraktikkan langsung ilmu yang dipelajari, satri juga dapat dikontrol dan di asuh oleh para kiai atau pengasuh dan para asatidz ${ }^{18}$ di pondok pesantren tersebut.

Bidang pengajaran (Dirosah/Tadris Wat Ta'liim ). Bidang ini mengemban tugas merancang program dan strategi pembelajaran serta pelaksanaannya dalam pembekalan materi keilmuan dan ketrampilan (life skill) yang bersifat klasikal. Program pembelajaran yang diberikan melalui proses belajar di kelas oleh para asatid yang diarahkan pada pengembangan intelegensi santri melalui kegiatan pengajaran (kognisi). Standart kompetensi yang tetapkan pada bidang ini meliputi:

1. Mampu mengerti dan memahami eksistensi Tuhan sebagai Tuhan yang disembah dan Tuhan yang menciptakan makhluk

2. Mampu memahami aturan Allah dan rosulnya baik yang berkaitan antara hubungan manusia dengan tuhan, manusia dengan manusia maupun manusia dengan sesame makhluk

3. Memiliki pengetahuan dan keterampilan dalam melakukan berbagai aktivitas pengembangan ilmu pengetahuan, teknologi dan seni sesuai dengan program studi yang ditempuh di perguruan tinggi.

4. Memiliki pengetahuan, keterampilan dan siap mengemukakannya secara lisan maupun tulisan hasil pengembangan ilmu pengetahuan, teknologi dan seni sesuai dengan program studi yang ditempuh di perguruan tinggi.

\footnotetext{
${ }^{17}$ Dokumen proofili pesantren mahasiswa Al-Hikam Malang Hlm 13-15

${ }^{18}$ Lanny Octavia dkk. Pendidikan karakter berbasis tradisi pesantren. Jakarta: Rumah
} Kitab. 2014. Hlm. xi 
5. Memiliki etos untuk terus belajar dan mengembangkan diri

6. Mampu mengembangkan cara berfikir kompleks

7. Mampu bekerjasama dan membangun team work

8. Memiliki tanggung jawab sebagai bagian dari masyarakatnya

Pelaksanaan bidang dirosah dimulai setelah melaksanakan shalat maghrib berjama'ah di masjid Al-Ghazali. kegiatan dirasah ini kurang lebih dilakukan selama 2 jam yang terdiri dari empat kelas yakni kelas 1, 2, 3, dan 4 yang ditempuh selama empat tahun. Kegiatan dirosah meliputi program pembelajaran yang terdiri atas:

1. Materi dasar yang bertujuan memberi bekal dasar-dasar pemahaman terhadap agama Islam dan pendalaman bahasa asing yang meliputi: Al Qur’an, Bahasa Arab, Bahasa Inggris, Fiqih Ibadah,

2. Materi pokok yang bertujuan untuk membentuk pola pikir serta penguasaan pengetahuan beserta metodologinya yangmeliputi; Fiqih mu'amalah, fiqih munakahat, aqidah, ilmu tafsir, ilmu hadits, logika mantiq, ushul fiqih, dan

3. Materi penunjang yang bertujuan untuk memperluas cakrawala pengetahuan santri meliputi ; ilmu komunikasi, manajemen, organisasi, dan kewirausahaan.

Bidang Kepengasuhan (Ri'ayah wal Irsyad). Bidang ini mengemban tugas penyampaian tausiyah, bimbingan dan arahan kepada Santri mahasiswa tentang nilainilai dan norma-norma agama serta persoalan kehidupan kemasyarakatan untuk mengarahkan dan membentuk para santri mahasiswa menjadi manusia yang beriman, berilmu dan beramal sholih. Program kepengasuhan ini menitik beratkan pada pembentukan jiwa santri atau pada tataran afeksi santri. Materi program ini diberikan kepada semua santri selama santri studi di Al Hikam dengan cakupan materi meliputi motto pesantren dan jiwa pesantren. Bentuk kegiatan yang dilakukan adalah pengajian Sabtu Pagi (mingguan), Istighotsah (mingguan), dan Tambih A'am (bulanan). Standart kompetensi yang tetapkan pada bidang ini meliputi:

1. Mampu memahami eksistensi Tuhan sebagai Dzat yang disembah dan menciptakan

2. Menguasai pengetahuan, ketrampilan dan siap mengemukakan secara lisan maupun tulisan hasil pengembangan pengetahuan, tehnologi dan seni sesuai dengan program studi yang ditempuh di perguruan tinggi.

3. Memiliki etos untuk terus belajar dan mengembangkan diri

4. Mampu mengembangkan cara berfikir kompleks 
5. Memiliki tanggung jawab sebagai bagian dari masyarakatnya.

Bidang Kesantrian (Ta'dib $W$ at Tabdrib) mengemban tugas mendampingi para santri mahasiswa dalam proses transformasi dan aktualisasi diri selama mereka tinggal di pesantren untuk mencapai tujuan pendidikan yang telah ditetapkan oleh pesantren. Program pendidikan bidang kesantrian lebih banyak didelegasikan kepada santri dalam hal ini terutama seluruh organisasi dan kegiatan santri di Al Hikam. Santri sebagai perencana, pelaksana dan sebagai evaluator pada setiap kegiatan. Sementara ustadz atau pembina adalah pendamping agar kegiatan tetap bisa terkontrol sehingga selain sebagai obyek, pada bagian ini, santri betul-betul sebagai subyek dalam pendidikan di pesantren.

Standart kompetensi yang tetapkan pada bidang ini meliputi:

1. Mampu mengerti dan memahami eksistensi Tuhan sebagai Tuhan yang disembah dan Tuhan yang menciptakan makhluk

2. Mampu memahami dan melaksanakan aturan Allah dan rosulnya baik yang berkaitan antara hubungan manusia dengan tuhan, manusia dengan manusia maupun manusia dengan sesame makhluk

3. Mampu merefleksikan/ menjalankan prinsip-prinsip tauhid dan syariah dalam tata cara perilaku yang baik.

4. Memiliki pengetahuan, keterampilan dan sikap dalam bidang keahlian tertentu sesuai dengan program studi (jurusan) yang ditempuh di perguruan tinggi.

5. Memiliki, pengetahuan, keterampilan dan sikap dalam melakukan berbagai aktivitas pengembangan ilmu pengetahuan, teknologi dan seni sesuai dengan program studi yang ditempuh diperguruan tinggi

6. Memiliki pengetahuan, keterampilan dan siap mengemukakannya secara lisan maupun tulisan hasil pengembangan ilmu pengetahuan, teknologi dan seni sesuai dengan program studi yang ditempuh di perguruan tingg

7. Mampu mendayagunakan potensi diri dan lingkungannya untuk peningkatan karir kerja

8. Memiliki etos untuk terus belajar dan mengembangkan diri

9. Mampu mengembangkan cara berfikir kompleks

10. Mampu berkomunikasi secara efektif

11. Memiliki tanggung jawab sebagai bagian dari masyarakatnya

12. Mampu bekerjasama dan membangun team work 
Guna melaksanakan tugas, bidang kesantrian dibantu oleh beberapa organisasi yang dibentuk yakni Organisasi Santri Pesantren Mahasiswa Al Hikam (OSPAM), Pos Kesehatan Pesantren (POSKESTREN) Al-Hikam Malang, dan Badan Dakwah dan Kesejahteraan Masjid (BDKM) Al-Ghozali.

1. Organisasi Santri Pesantren Mahasiswa Al Hikam (OSPAM)

OSPAM adalah organisasi santri yang mewadahi aktualisasi diri, penyaluran bakat-minat dan bertugas melakukan pengaturan aktivitas dan kebuuhan seluruh santri. OSPAM terbentuk atas prakarsa dari santri Pesantren Mahasiswa Al-Hikam Malang. OSPAM terbentuk ketika jumlah santri mulai berambah dari yang semula hanya belasan orang. Bertambahnya jumlah santri ini berarti juga semakin bertambah aktivitas keseharian, kebutuhan yang menuntut adanya pengaturan, dan perlunya media apresiasi terhadap minat dan bakat santri.

Seluruh kegiatan OSPAM direncanakan, dilaksanakan, dan dievaluasi oleh santri secara mandiri dalam menjalankan tugas dan aktivitasnya, sementara Pembina (dewan kesantrian) berperan sebagai pendamping. Melalui OSPAM ini diharapkan akan terlatih dan terbina sikap-sikap antara lain: kepemimpinan, kreativitas, inisiatif, dan keberanian para santri dengan tetap mengedepankan etika dan moral. Sebagaimana yang sering disampaikan Bapak Pengasuh bahwa salah satu pilar dari mekanisme kerja OSPAM hendaknya selalu dijunjung tinggi sikap yang demokratis tapi etis.

Salah satu bentuk upaya mewujudkan kepemimpinan dan kepengurusan yang demokratis, pengurus OSPAM dipilih secara demokratis melalui mekanisme RTO (Rapat Tahunan OSPAM) yang diselenggarakan sekali dalam satu tahun periode kepengurusan. Forum ini wajib diikuti oleh seluruh santri Pesantren Mahasiswa AlHikam Malang sehingga forum ini bersifat "dari santri, oleh santri, dan untuk santri". Agenda dalam RTO meliputi pembahasan laporan pertanggungjawaban (LPJ) dan evaluasi kepengurusan OSPAM yang akan didemisioner, pembahasan AD/ART OSPAM, sidang komisi untuk merencanakan program kerja OSPAM periode selanjutnya, serta diakhiri pemilihan tim formatur yang akan menjadi Ketua Umum, Ketua I, dan Ketua II.

2. Pos Kesehatan Pesantren (POSKESTREN) Al-Hikam Malang

Pos Kesehatan Pesantren merupakan salah satu wujud UKBM di lingkungan pondok pesantren, dengan prinsip dari, oleh, dan untuk warga pondok pesantren, 
yang mengutamakan pelayanan promotif (peningkatan) dan preventif (pencegahan) tanpa mengabaikan aspek kuratif (pengobatan) dan rehabilitatif (pemulihan kesehatan), dengan binaan Puskesmas setempat. POSKESTREN Al-Hikam Malang berdiri pada Bulan Juli 2008 berdasarkan Surat Keputusan Yayasan Al-Hikam Malang Nomor 41.Al-Hikam.07.2008 yang ditetapkan pada tanggal 1 Juli 2008.

Secara umum, POSKESTREN Al-Hikam Malang bertujuan untuk mewujudkan kemandirian warga pesantren dan masyarakat sekitar dalam berperilaku hidup bersih dan sehat. Kegiatan POSKESTREN Al-Hikam Malang meliputi pemberian penyuluhan kesehatan kepada warga pesantren dan masyarakat sekitar, memberikan pelayanan kesehatan dasar bagi warga pesantren, survei lingkungan pesantren, penyelenggaraan cek kesehatan dan donor darah, dan sebagainya.

3. Badan Dakwah dan Kesejahteraan Masjid (BDKM) Al-Ghozali.

Badan Dakwah dan Kesejahteraan Masjid atau yang disingkat dengan BDKM Al-Ghozali Pesantren Mahasiswa Al-Hikam Malang merupakan organisasi yang berdiri pada tahun 2004. Pada mulanya badan ini bernaung dibawah bidang kesantrian dan OSPAM. Namun setelah beberapa tahun ruang gerak badan ini kurang dirasakan oleh pesantren. Berdasarkan kesepakatan jajaran pengurus periode 2004 serta disetujui oleh pihak pesantren, bahwa dalam rangka mengoptimalkan fungsi-fungsi dakwah serta menjaga keberlangsungan kemakmuran dan kesejahteraan masjid di lingkungan Pesantren Mahasiswa Al-Hikam Malang, maka diperlukan organisasi dan kejelasan personalia pengurus yang dalam pelaksanaan tugas dan wewenangnya bertanggung jawab kepada pengasuh melalui kepala Pesantren Mahasiswa Al-Hikam Malang.

BDKM Al-Ghozali berfungsi sebagai pusat laboratorium religi bagi santri dan media dakwah bagi masyarakat sekitar dan untuk semua elemen masyarakat. Dalam perkembangannya BDKM Al-Ghozali memiliki binaan adik yatim piatu dari lingkungan sekitar pesantren yang tergabung dalam Gerakan Peduli Anak Yatim (GPAY) Al-Hikam Malang. Bentuk pembinaan yang dilakukan oleh pengurus BDKM Al-Ghozali berupa pembinaan keagamaan dan pembinaan pengetahuan umum, pemberian santunan setiap bulan, dan sebagainya.

Tradisi Pesantren Al-Hikam Pesantren Mahasiswa Al-Hikam adalah sebuah keluarga besar yang terdiri dari beberapa unsur dan pihak yang terlibat di dalamnya. Semua unsur dan pihak yang ikut berperan di Pesantren Mahasiswa Al-Hikam 
menjalin hubungan yang harmonis dan dinamis baik secara kelembagaan maupun antar personal, yang diwarnai oleh suasana kekeluargaan yang damai penuh rasa kasih sayang.

Pesantrean Mahasiswa Al-Hikam senantiasa menjaga dan merawat suasana hubungan tersebut. Iklim yang positif, sehat dan harmonis ini diharapkan dapat membantu proses realisasi dan dan aktualisasi diri bagi santri, guru, staf dan seluruh keluarga besar pesantren.

Selain itu, Pesantren Mahasiswa Al-Hikam juga melibatkan partisipasi para wali santri, masyarakat sekitar serta alumni guna menjaga hubungan yang harmonis berdasarkan ruhul ma'had. ${ }^{19}$ Yaitu Ikhlas dalam beramal, Jujur dalam bersikap, Sederhana dalam hidup, Santrun dalam bergaul, Mandiri dalam berusaha, Berjuang bersama-sama.

Kedisiplinan di Pesantren Mahasiswa Al-Hikam dirancang untuk mendorong terciptanya kondisi lingkungan sosial yang sehat, aman, nyaman dalam rangka membentuk santri yang mandiri, sadar, dan bertanggung jawab dalam setiap sikap, perilaku, dan tindakan.

Aturan di pesantren Al-Hikam didesain sederhana dan simpel untuk mendorong para santri melaksanakan tugas dan kewajiban dan amanah yang berkaitan dengan ibadah, diri sendiri, sesama teman, guru, kiai, dan masyarakat. Tata tertib Pesantren Mahasiswa Al-Hikam mendorong penerapan perilaku sopan santu dan mendahulukan kepentingan sesama, saling menghormati dan menghargai untuk menciptakan komitmen dan kesadaran ukhuwah islamiah.

Pihak pengasuh dan asatidz bertugas sebagai fasilitator dan pendamping dalam proses peningkatan dan pengembangan diri serta aktualisasi diri para santri. Dalam praktiknya, para santri diarahkan untuk memiliki kemandirian, melihat dan dan memahami konsekuensi pilihan dan sikap yang ditempuhnya, serta memecahkan persoalan dan permasalahan mereka sendiri. ${ }^{20}$

\section{Kesimpulan}

Implementasi pendidikan karakter di pesantren mahasiswa Al-Hikam merupakan salah satu bentuk dari usaha lembaga pendidikan non formal untuk turut

\footnotetext{
${ }^{19}$ Dokumen proofili pesantren mahasiswa Al-Hikam Malang Hlm 61

${ }^{20}$ Dokumen proofili pesantren mahasiswa Al-Hikam Malang Hlm 65.
} 
mencerdaskan dan membantu pemerintah dalam meningkatkan harkat dan martabat bangsa. Proses perencaan pendidikan karakter, melalui kurikulum terintegrasi antara tiga komponen utama pesantren yakni, kepengasuhan, dirasah, dan kesantrian ditambah empat lainnya yaitu tradisi pesantren, jiwa pesantren, kedisiplinan, dan struktur organisasi/manajemen dapat dijadikan bahan rujukan dalam meningkatkan mutu pendidikan karakter di Indonesia.

Pelaksanaan pendidikan selama 24 jam di pondok pesantren meliputi pendidikan Ri'ayah wal Irsyad (kepengasuhan), Ta'dib wat Tabdrib (kesantrian), dan Dirosab/ Tadris Wat Ta'liim (Pengajaran) ditambah empat pendukung lainnya yang sudah di paparkan di atas merupakan salah satu sistem pendidikan yang perlu terus dikembangkan dan menjadi bahan rujukan dalam implementasi pendidikan karakter Islam di era milenial saat ini.

\section{Daftar Rujukan}

al-Ghazaly, Abi Hamid Muhammad bin Muhammad. Ibya’ ulumuddin. juz 3.

Dokumen Profil Berdirinya Pesantren Mahasiswa Al-Hikam Malang. 2016.

http://msaa.uin-malang.ac.id/sample-page/ diakses 1 Oktober 201. Jam 10.38 Am.

Lalo, Kalfaris. Menciptakan Generasi Milenial Berkarakter dengan Pendidikan Karakter guna Menyongsong Era Globalisasi. Jurnal Ilmu Kepolisian Volume 12 Nomor 2 Juli 2018.

Mike Frye, at all. Character Education Informational Handbook and Guide. Public Schools of North Carolina State Board of Education Department of Public Instruction Division of Instructional Services Character Education. 2002.

Nurina, Siti Hakim dan Aliffatullah Alyu Raj. Dampak kecanduan internet (internet addiction) pada remaja. Prosiding Temu Ilmiah X Ikatan Psikologi Perkembangan Indonesia.

Octavia, Lanny dkk. Pendidikan karakter berbasis tradisi pesantren. Jakarta: Rumah Kitab. 2014.

Putra, Yanuar Surya. Theoritical Review: Teori Perbedaan Generasi. Among Makarti. Vol.9 No. 18. Desember 2016.

Ryan, Kevin dan Karen E Bohlin. building charakter in schools Practical ways to bring moral intruction to life. San Fransisco:Jossey-Bass Publishers. 1999. 
TA'LIMUNA, Vol. 9, No. 02, September 2019, ISSN 2085-2975

Said, Akhmad. "Kepemimpinan Kepala Sekolah Dalam Melestarikan Budaya Mutu Sekolah." journal EVALUASI 2.1 .2018.

Sugono, Dendy dan Meity Taqdir Qodratillah (eds). Kamus Bahasa Indonesia Jakarta: Pusat Bahasa, 2008.

Umro, Jakaria. Pendidikan Karakter Dalam Perspektif Islam ( Kajian Penerapan Pendidikan Karakter Anak dalam Keluarga ) Jurnal Al-Makrifat Vol 2, No 1, April 2017. 